\title{
A numerical investigation of velocity and temperature distribution on a heat sink with hexagonal fins facing at different angles in a rectangular duct
}

\author{
Dikdörtgen kesitli bir kanal içerisinde farklı açılara sahip altıgen kanatçıkl yüzeylerde hız \\ ve sıcaklık dağılımının nümerik olarak incelenmesi
}

\author{
İlhan Volkan ÖNER*1,a \\ ${ }^{1}$ Ataturk University, Faculty of Engineering, Department of Mechanical Engineering, 25240, Erzurum
}

• Geliş tarihi / Received: 15.07.2021 • • Düzeltilerek geliş tarihi / Received in revised form: 23.10.2021 • Kabul tarihi / Accepted: 09.11.2021

\begin{abstract}
The cooling of hot surfaces through drawing heat by means of fins attached to the surface is widely used technique in many systems. The fins increase the heat transfer surface area, thereby improving the heat transfer. In this study, the velocity and temperature distributions of the working fluid, air, flowing at constant temperature and constant Reynolds numbers over the hexagonal fins, placed in a rectangular duct, having the same surface area and same arrangement but facing at different angles to the flow plane; $0^{\circ}, 15^{\circ}$ and $30^{\circ}$, were analyzed numerically. Computational fluid dynamics (CFD) analysis was carried out with Ansys Fluent. The results were obtained for pressure drop, temperature and velocity distributions at all angles $\left(0^{\circ}, 15^{\circ}\right.$ and $\left.30^{\circ}\right)$. As a result of the analyses performed, $15^{\circ}$ facing angle was concluded to be the best by the virtue of the fact that the heat transfer coefficient was improved by the renewal of the boundary layer and by the turbulence occurred between the fins.
\end{abstract}

Keywords: Ansys-Fluent, CFD, Fin facing angle, Heat transfer

$\ddot{\boldsymbol{O}} z$

Isınan yüzeylere kanatçık ilavesi ile ısı çekilerek yüzeyin soğutulması işlemi birçok sistem için yaygın olarak kullanılmaktadır. Kanatçıklar ısı transfer yüzey alanlarını arttırarak ısı transferinin iyileşmesini sağlanmaktadırlar. Bu çalışmada, dikdörtgen bir kanal içine aynı yüzey alanına sahip, aynı dizilimde $0^{\circ}, 15^{\circ}$ ve $30^{\circ}$ farklı açılarla yerleştirilen altıgen şeklindeki kanatçıkların üzerinden sabit sıcaklık ve sabit Reynolds sayılarında akan iş akışkanı havanın hız ve sıcaklık dăğlımları Ansys Fluent paket programı kullanılarak numerik olarak analiz edilmiştir. Yapılan analizler $15^{\circ}$ dizileme sahip kanatçıklarda, sınır tabakanın yenilenmesinden ve kanatçıklar arasında oluşan türbülanstan dolayı ısı transfer katsayısının iyileştiği sonucuna varılmıştır. Hesaplamalı akışkanlar dinamiği (CFD) analizi, Ansys Fluent paket program ile gerçekleştirilmiştir. Çalışmadan elde edilen sonuçlarda tüm kanatçık açılarında $\left(0^{\circ}, 15^{\circ}\right.$ ve $\left.30^{\circ}\right)$ basınç düşümü, sıcaklık ve hız dă̆llımları gösterilmişstir.

Anahtar kelimeler: Ansys-Fluent, CFD, Kanatçık dizilim açısı, Isı transferi

${ }^{*}$ a İlhan Volkan ÖNER; ivoner@atauni.edu.tr, Tel: (0442) 23146 23, orcid.org/0000-0003-3065-0189 


\section{Introduction \\ 1. Giriş}

In studies to improve heat transfer in heat exchangers; it is desirable to reduce weight and size, while increasing the amount of heat transferred, and decreasing the average temperature difference between fluids, and thus improve overall efficiency. Improving heat transfer usually includes techniques such as increasing the surface area, making changes on the surface or creating turbulence in the flow (Sundén, 1999).

Heat transfer is of great importance in the design of various engineering systems such as heat exchangers, boilers, nuclear reactors, solar collectors, heaters, coolers, internal combustion engines, thermal turbo engines, gas turbines, combustion chambers, electrical machines, transformers, etc. In such systems, the main concern is to maximize the heat transfer per unit time and to protect the structural integrity and strength of materials exposed to high temperatures. In parallel to the studies conducted to overcome or alleviate such concerns, the need for heat exchangers with reduced sizes is also increasing day by day (Kotcioglu and Bolukbasi, 2003).

One modern solution, being widely applied, to overcome cooling problems is to increase the heat transfer surface area by means of fins. Fins increase the convective heat and mass transfer by not only by increasing the surface area but also by increasing the turbulence of the flow. Finned surfaces have a wide range of applications, including but not limited to cooling of turbine blades in gas turbine engines, cooling of electronic devices, or in various heat exchangers in aircrafts or chemical production facilities. However, improper use of fins can reduce heat transfer rather than increase it. For this reason, the fin material, type, placement arrangement, form of surfacemounting and ambient conditions should all be considered and evaluated in a way to increase heat transfer. In the heat exchangers, the decrease in the amount of heat transferred causes the performance of the heat exchanger to decrease and hence a capacity loss in the system it is being used. Improved heat transfer, enables the system size to be kept at optimum and thus allows reduced system cost and operating costs. Many theoretical and experimental studies conducted aiming to analyze heat transfer and flow structures in plate heat exchangers are available in the literature.

Various heat exchanger models have been developed. In order to develop such optimized designs, it is necessary to determine the heat transfer coefficient and flow properties of the surface geometry as well as the pressure loss coefficient. Another method to improve heat transfer is to renew the boundary layer, which has been reported in previous studies (Briggs and London, 1960; Kays and London, 1954). On natural convection, analytical and experimental studies have been carried out between parallel plates (Briggs and London, 1960; Kays and London, 1954; Kotcioglu and Bolukbasi, 2003; Masao et al., 1988; Maughan and Incropera, 1991). In industrial applications, expanded surfaces and heat exchanger applications have become increasingly important. heat transfer experiments at low Reynolds numbers via forced convection have been performed in such applications (Masao et al., 1988).

Tauscher and Mayinger (1999) investigated experimentally and numerically, the increase in the heat transfer in tablet-type heat exchangers for laminar and low turbulent flow rates induced by using fins in different arrangements (Tauscher and Mayinger, 1999). Using a CFD model, Lee and Abdel-Moneim (2001) investigated the heat transfer and flow behavior on the horizontal surface with two-dimensional flat bars (Lee and Abdel-Moneim, 2001). Acharya et al. (1993) investigated experimentally and numerically the flow and heat transfer in a channel with pins fins for a periodically developing flow field (Acharya et al., 1993). Buyruk and Karabulut (2017) conducted a numerical three dimensional investigation of the effect of fin geometry on heat transfer in plate fin heat exchangers (Buyruk and Karabulut, 2017). Karabulut et al. (2013) in another study, numerically investigated the effects of two different fin types (zigzag and outer zigzagstraight-outer zigzag) on heat transfer with the combined (convection and conduction) heat transfer approach to increase heat transfer in finned plate heat exchangers (Karabulut et al., 2013).

In another study, the heat transfer in interconnected finned elements was shown to be greater than it is in detached elements and results from similar studies were presented. (Masao et al., 1988; Russell and Lee, 2005). These types of flow geometries are widely used in industrial applications and computer technology. Studies have shown that expanded surfaces are an effective method of increasing heat transfer. As a result of similar studies, by Mendes and Sparrow (1984), Garg and Maji (1988) and Kotcioğlu and Ayhan (1998), it was concluded that such applications increase heat transfer.(Garg and 
Maji, 1988; Kotçioğlu et al., 1998; Souza Mendes and Sparrow, 1984).

Wang et al. (2009) analyzed flow and heat transfer characteristics for flat and serrated finned plate heat exchangers. Numerical simulations for two-fin heat exchangers at low Reynolds numbers were performed using CFD code, FLUENT (Wang et al., 2009). Wen et al (2016; 2018) carried out optimization of a serrated fin plate heat exchanger using Kriging the surface method (Wen et al., 2018; Wen et al., 2016).

Mesler (1993), in this study, in the spray cooling of a heated surface, a new method for determining and designating the surface texture was proposed, and the effects of surface roughness on evaporation/nucleation in the spray cooling flow field were studied. Moreover, A one-dimensional Fourier analysis had applied to determine experimentally the surface profile of a surface polished with emery paper covering a spectrum of grit sizes between 0.3 micron to 22 microns (Mesler, 1993).

Hung et al. (2019), examined the effects of different size and arrangement of pin fins on heat transfer in a rotating rectangular duct. The results revealed awakening flow which contributes to flow acceleration, separation, and heat transfer contours. The larger the pins become higher local flow rates and higher heat transfer between the fins occurred. The rotational effect of the channel improved heat transfer on both the front and back surfaces. When larger sized pins were added to the fin array, the friction factor ratio increased (Hung et al., 2019).

Soleymani et al., (2020), conducted in their study a numerical analysis of pin fins for the hot zone in a microchannel heat sink. The numerical results showed that increasing the wall wave amplitude increases the heat transfer rate (Soleymani et al., 2020).

Ahmadian-Elmi et al. (2021), in their study, performed a comprehensive optimization of pin-fin heat sinks in five stages to find the best hydrothermal performance according to the figure of merit criterion. Features such as number of blades, blade height, blade diameter and transverse pitch were chosen as geometric parameters. In addition, a new pin-fin was designed (conical pinfins) and its geometric parameter (conical ratio) was optimized (Ahmadian-Elmi et al., 2021).

Adhikari et al. (2020) presented an analysis of heat transfer properties in natural convection and flow patterns of optimum rectangular fin configurations for fin design optimization. They also performed three-dimensional, steady-state laminar heat transfer simulations to analyze the optimum fins of rectangular fins that were experimentally tested in the literature (Adhikari et al., 2020).

When the above studies are examined, it can clearly be seen that all focus on the effects of the geometry and the structure of fins on heat transfer in heat exchangers, either experimentally and/or numerically. In these studies, limited changes were taken into consideration and the effects of those changes on thermal performance were investigated. In this study also, geometric parameters are discussed in order to examine the effect fins, having the same surface area and shape, on thermal performance. The limitations caused by the change in the arrangement of fins between each other were determined and the effects thereof on the thermal performance and hydrodynamic behavior were examined. In a heat exchanger model having hexagonal fins placed at different facing angles, under turbulent flow and certain boundary conditions, the effects of facing angle on heat transfer, pressure drop and flow velocity were investigated using the Finite Volume Method and ANSYS Fluent software. According to the heat transfer values calculated based on the exit air temperature and convection coefficient found determined in the analysis, the best facing angle is proposed.

\section{Material and method}

\section{Materyal ve metot}

\subsection{Numerical method}

2.1. Nümerik Metot

Numerical solution has been carried out as threedimensional, time-independent, and with combined (conduction and convection) heat transfer approach. Finite volume method, in FLUENT, was used to solve the combined heat transfer analysis.

The finite volume method is based on the principle of dividing the geometry to be analyzed into portions, obtaining a solution for each of which, and then acquiring the general solution of the problem by combining these partial solutions. In the finite volume method, a control volume-based technique is used to transform the conservation equations into numerically solvable algebraic equation systems. This technique involves integrating the conservation equations for each control volume, resulting in discrete equations that 
provides the control volume for the variables. With the iterative solution of systems of linear equations, obtained by linearization of discrete equations, variables such as velocity, pressure and temperature are updated until they prove the given convergence measure. In order to provide the most suitable mesh structure, a higher mesh density should be created in regions with greater changes in velocity, pressure or temperature. For this reason, the duct surfaces with the fins are the parts with the highest mesh density, and a lighter mesh structure is preferable in other regions.

As the fins used in the flow region cause turbulence, realizable k- $\varepsilon$ turbulence model was determined to be appropriate in numerical models for finned geometries. Therefore, Realizable k- $\varepsilon$

turbulence model was used in the calculations in this study.

The analyses of flow and heat transfer across the whole geometry is based on the time independent solution of partial differential equations derived from the laws of conservation of mass (continuity equation), momentum and energy, which can be written as follows, respectively (Mesler, 1993).

Continuity equation:

$\nabla \cdot(\rho V)=0$

Momentum Equation:

$\nabla \cdot(\rho V V)=-\nabla P+\nabla \cdot\left[\mu\left(\nabla V+\nabla V^{\prime}\right)\right]$

Energy conservation equation:

$u \frac{\partial T}{\partial x}+v \frac{\partial T}{\partial y}+w \frac{\partial T}{\partial z}=\left(\frac{k}{\rho C_{p}}\right)\left(\frac{\partial^{2} T}{\partial x^{2}}+u \frac{\partial^{2} T}{\partial y^{2}}+u \frac{\partial^{2} T}{\partial z^{2}}\right)$

The turbulence kinetic energy equation for steady flow is written as follows:

$\frac{\partial(\rho u k)}{\partial x}+\frac{\partial(\rho v k)}{\partial y}+\frac{\partial(\rho w k)}{\partial z}=\frac{\partial}{\partial x}\left(\frac{\mu_{t}}{\sigma_{k}} \frac{\partial k}{\partial x}\right)+\frac{\partial}{\partial y}\left(\frac{\mu_{t}}{\sigma_{k}} \frac{\partial k}{\partial y}\right)+\frac{\partial}{\partial z}\left(\frac{\mu_{t}}{\sigma_{k}} \frac{\partial k}{\partial z}\right)+\mu_{t} \varphi-\rho \varepsilon$

and the turbulent viscosity is given in equation 5 :

$\mu_{t}=C_{\mu} \cdot \rho \cdot \frac{k^{2}}{\varepsilon}$

In the turbulence kinetic energy equation, $\mathrm{k}$ is:

$k=\frac{1}{2}\left(\overline{u^{2}}+\overline{v^{2}}+\overline{w^{2}}\right)$

The viscous dissipation term is also given as in equation 7 below:

$\varphi=2 \mu\left[\left(\frac{\partial u}{\partial x}\right)^{2}+\left(\frac{\partial v}{\partial y}\right)^{2}\right]+\mu\left(\frac{\partial v}{\partial x}+\frac{\partial u}{\partial y}\right)^{2}$

Since the thermal conductivity of the fin material affects the thermal distribution along the channel, the selection of the fin material is an important factor in increasing the heat transfer. Therefore, aluminum, which has high thermal conductivity, is cheap and light, has been chosen as the fin material. The thermal resistance between the fins and channel surface was neglected assuming that the fins were produced as a one piece with channel.

\subsection{Geometry}

2.2. Geometri

In this study, the heat transfer in a rectangular duct with twenty-five hexagonal fins in the case of an air flow at $19{ }^{\circ} \mathrm{C}$ was numerically investigated.
Figure 1 shows the schematic view and dimensions of the model that was used in the analysis. The height, width and length of the rectangular duct is $8 \mathrm{~cm}, 12 \mathrm{~cm}$ and $95 \mathrm{~cm}$, respectively.

In Figure 2 are the three arrangements of the twenty-five identical hexagonal fins placed in the channel at different facing angles. In the computation, the working fluid was selected to be air and was modeled as a Newtonian fluid. Flow was regarded as incompressible and the flow was assumed to be laminar due to the low inlet velocity. Besides, the radiative heat transfer and effect of gravity were neglected in this study. The channel material was chosen as aluminum, and the effects of surface roughness were ignored. It was also assumed that the inlet temperature of the fluid in the channel was assumed to be constant at $19{ }^{\circ} \mathrm{C}$ and that the temperature of the bottom plate was constant at $40{ }^{\circ} \mathrm{C}$. By applying constant heat flux to bottom wall, heat transfer took place from the bottom wall to the air passing by. The velocity of air entering the channel was determined as constant at $2 \mathrm{~m} / \mathrm{s}$ in the numerical study, and its thermophysical properties for $\mathrm{T}_{\text {inlet }}=19^{\circ} \mathrm{C}$ were obtained as given below in Table 1. Here, $\mu$ is the dynamic viscosity, $\rho$ is the density, $c_{p}$ is the specific heat and $\mathrm{k}$ is the thermal conductivity. 


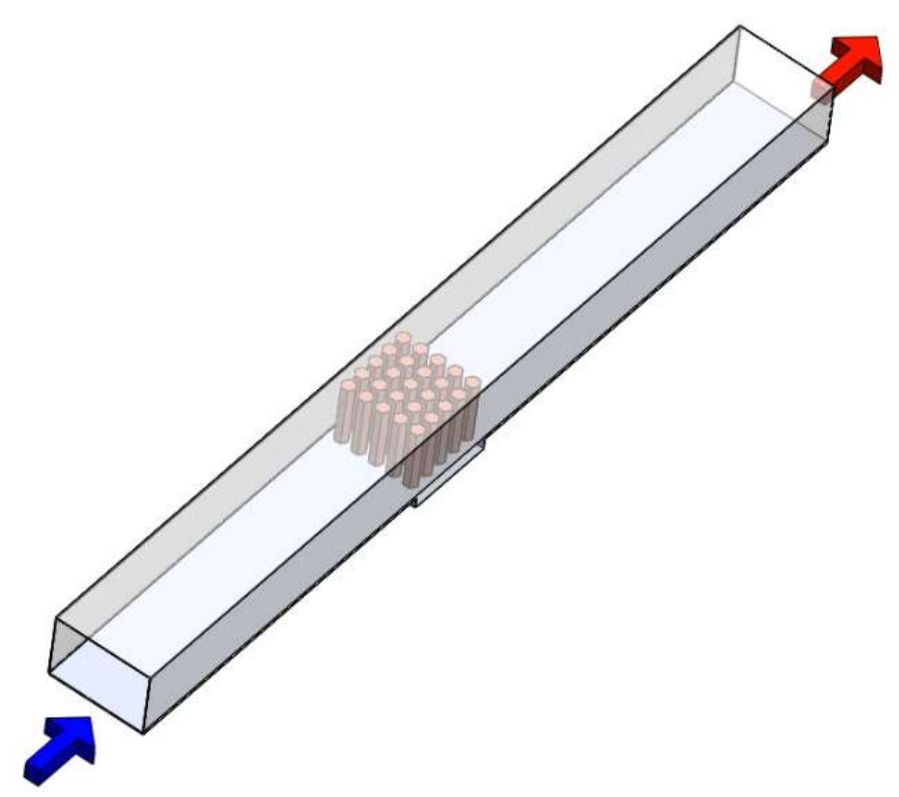

Figure 1. Designed model

Şekil 1. Tasarlanan model

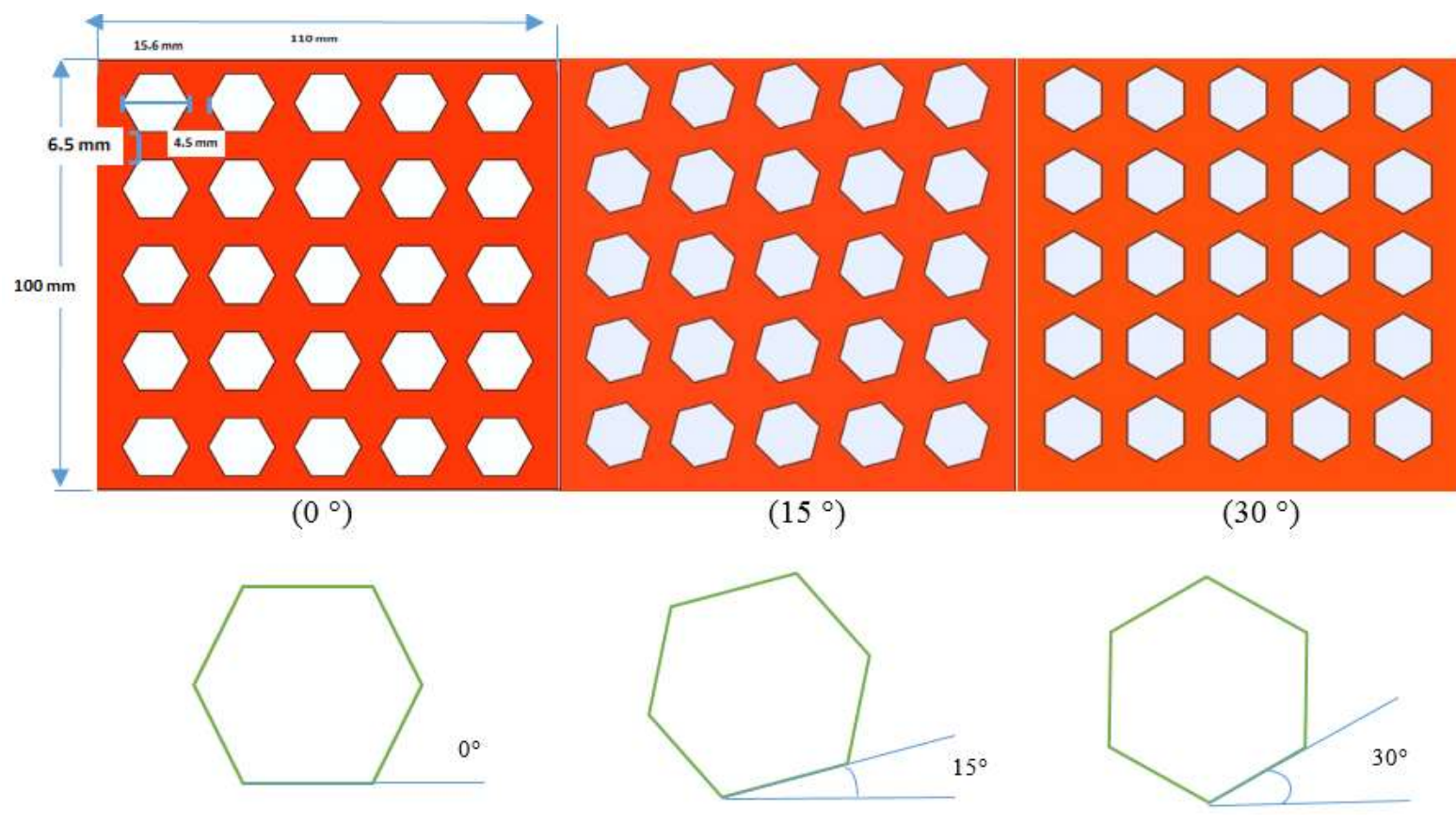

Figure 2. Arrangement of hexagonal fins at different facing angles

Şekil 2. Farklı yüzey açılarında altıgen kanatçıların yerleştirilmesi

Table1. Thermo-physical properties for inlet air ( $\left.\mathrm{T}_{\text {inlet }} @ 19^{\circ} \mathrm{C}\right)$

Tablo 1. Giriş havasının termo-fiziksel özellikleri ( $\left.T_{\text {inlet }} @ 19^{\circ} \mathrm{C}\right)$

\begin{tabular}{|c|c|}
\hline$\mu \quad(\mathrm{kg} / \mathrm{ms})$ & $1.7894 \times 10^{-5}$ \\
\hline $\mathrm{k} \quad(\mathrm{W} / \mathrm{mK})$ & 0.0242 \\
\hline$c_{p}(J / k g K)$ & 1006.44 \\
\hline$\rho \quad\left(\mathrm{kg} / \mathrm{m}^{3}\right)$ & 1.225 \\
\hline
\end{tabular}

\subsection{Meshing and mesh validation}

2.3. Mesh ve mesh doğrulama

For the computational fluid dynamics (CFD) part of the study, ANSYS Workbench-16 (Fluent) software was used as solver. ANSYS (Fluent) is a package program that can solve problems such as external pressures and forces, constant inertia forces, displacements based on heat transfer. This program is also used for the structural computation part. Various element types are used in static structural analysis. In this study, hybrid mesh 
generation was preferred in order for the prism layer in the hybrid network to solve the boundary layer efficiently. In short, in the finite element method, the element to be analyzed is divided into small sub-elements in order to obtain a solution.
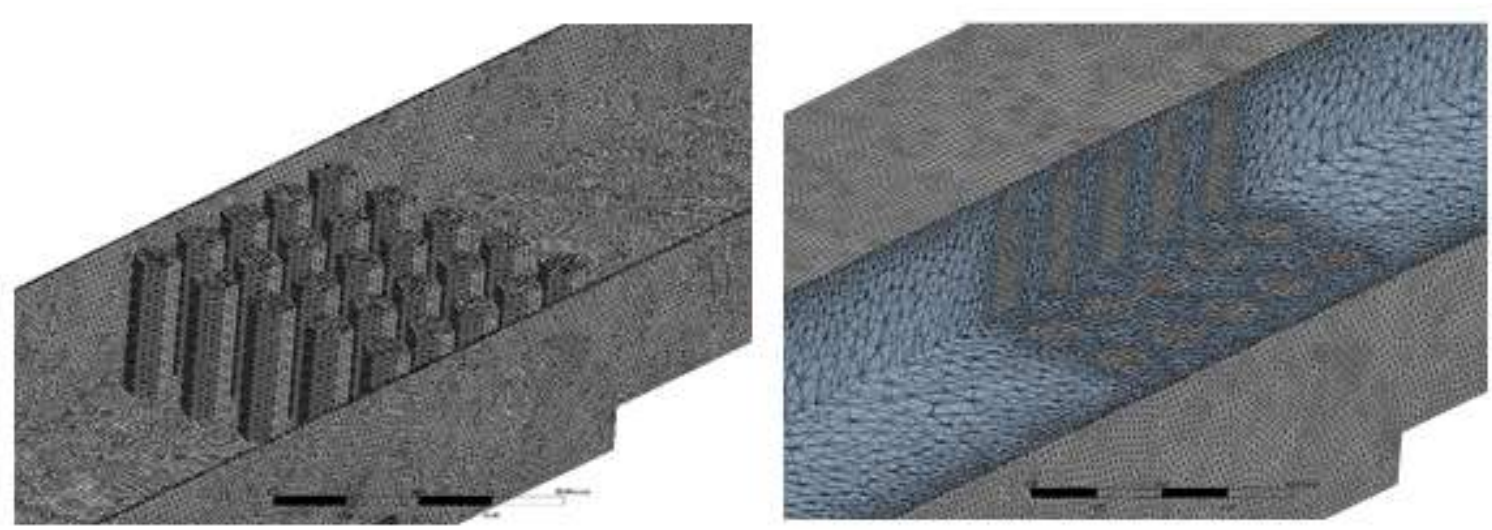

Figure 3. Meshing of model

Şekil 3. Modelin meshlenmesi

In this study, as seen in the images of the mesh model in figure 3, after the mesh was generated using finite elements method and compiled, the function in the interpreted code or shared library
Patch Independent Mesh method for Tetrahedrons allows for mesh refinement when necessary, however it can also preserve larger elements that enables faster computation.

that appeared in the drop-down lists in the dialog boxes was applied on the CFD model.

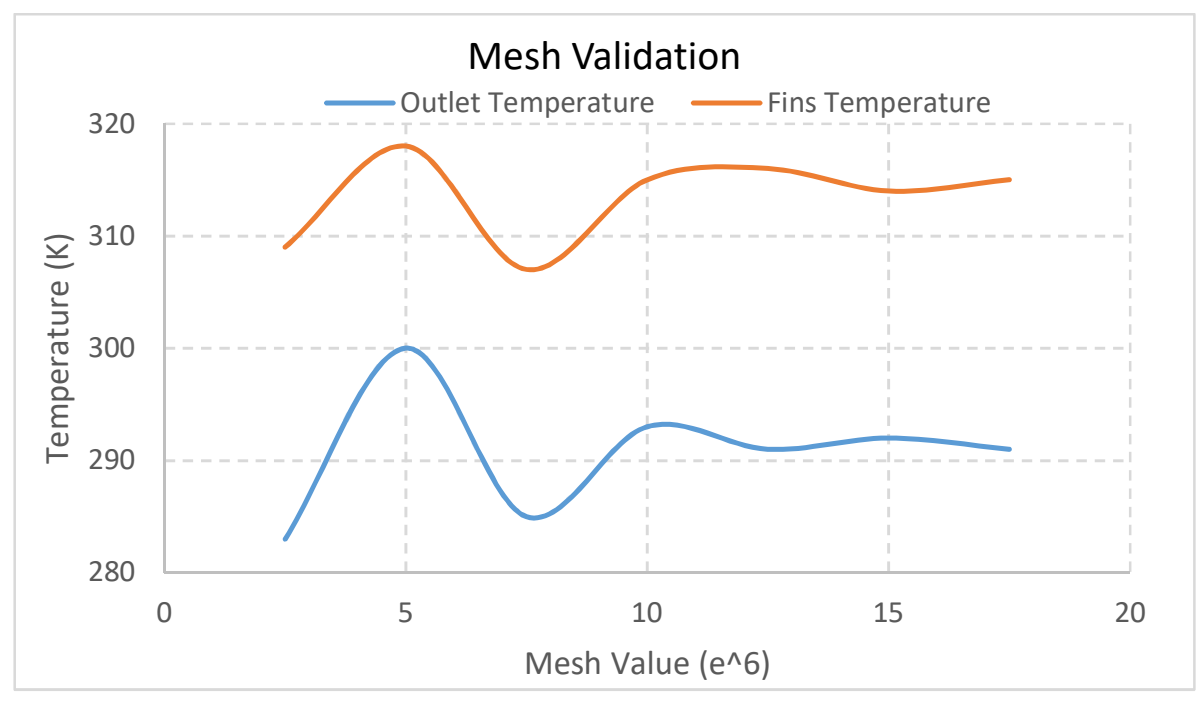

Figure 4. Mesh Validation Diagram according to exit temperature and fin temperature Şekil 4. Çıkışsıcaklığına ve kanat sıcaklığına göre mesh doğrulama şeması

Figure 4 shows the dispersion of exit and fin temperatures. The best mesh count, i.e. the number of elements, flattens after about 10 million nodes. In this study, the calculations started approximately at 11.268.753 number of elements. The modeling and solution network was created in the ANSYS
Workbench interface while the boundary conditions the solutions of conservation equations were carried out in the Fluent interface. A solution network, in tetrahedral and hexahedral network structure, of the rectangular channel model was created. 


\section{Results and discussion}

3. Sonuçlar ve tartışma

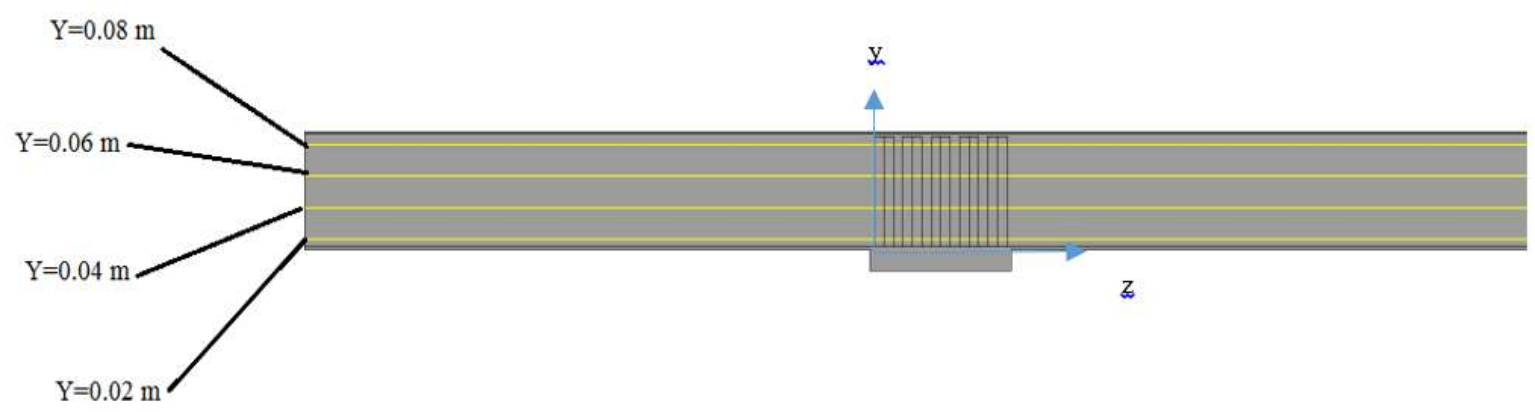

Figure 5. Analysis lines in the middle and along the channel

Şekil 5. Ortada ve kanal boyunca analiz çizgileri

Figure 5 shows the imaginary lines that passes across the control volume and the channel along which the change of velocity and temperature were analyzed.
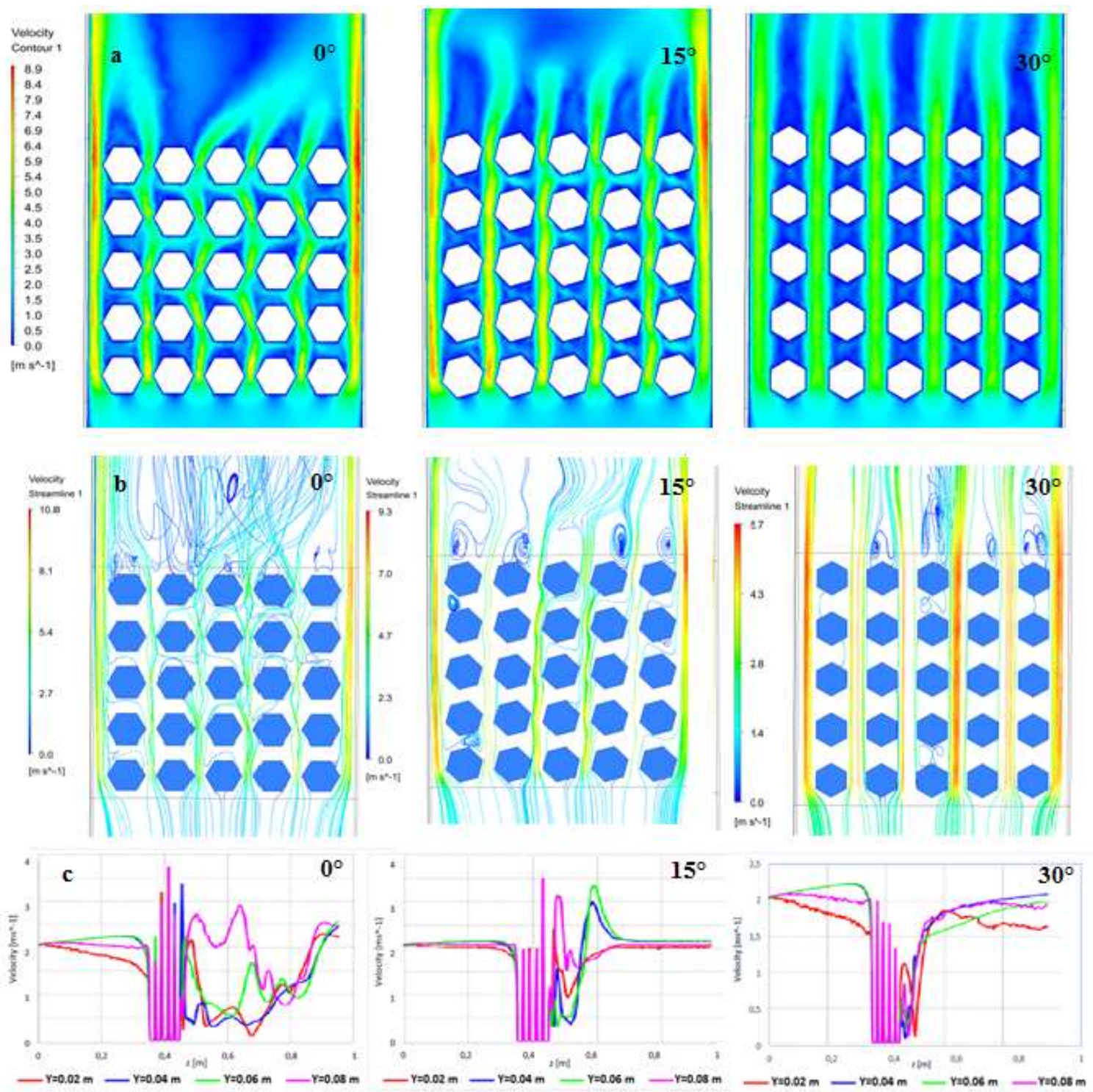

Figure 6. (a) Velocity distribution units (b) Dominant velocity lines (c) Velocity values on different lines in the channel

Şekil 6. (a) Hız dă̆̆lım birimleri (b) Baskın hız çizgileri (c) Kanaldaki farklı hatlardaki hız değerleri 
Figure 6 (a) shows velocity distributions for hexagonal fins placed at different facing angles. According to these distributions, the air flowing from the bottom towards the top hits the flat surface of the hexagonal fin aligned at $0^{\circ}$ to the crosssectional plane of the channel, thus partially subjected to turbulence and leaves the finned section of the channel by accelerating on the fin and the channel surface. It can be said that at $0^{\circ}$ the velocity is partially increased on the inter-fins zone. When the hexagonal fins were rotated by $15^{\circ}$, this angular rotation increased the velocity profile both longitudinally within the fins and along the channel surface. With $30^{\circ}$ rotation, the corners of the hexagonal fins became perpendicular to the flow direction, it is seen that the air velocity increased longitudinally between the fins and the turbulence decreased. In addition, it is noteworthy that the regions where the air velocity slowed down is greater in this arrangement.

When the dominant velocity lines in Figure 6 (b) are examined; in the $0^{\circ}$ facing arrangement, it is seen that the velocity between the fins drops drastically, and the velocity lines progress chaotically in a random manner beyond the last row of fins. In the $30^{\circ}$ facing arrangement, it is seen that the longitudinal velocity between the fins increase, and the velocity vortices are formed behind the fins. Finally, in the $15^{\circ}$ facing arrangement, both between the fins and behind the last row of fins, the velocity increases and flow becomes turbulent.

Seen in Figure 6 (c) is the variation of velocities along the assumed axes $(0.02 \mathrm{~m}, 0.04 \mathrm{~m}, 0.06 \mathrm{~m}$ and $0.08 \mathrm{~m}$ ) that pass across the fins in the $\mathrm{z}$-axis for each of the three fin arrangements $\left(0^{\circ}, 15^{\circ}\right.$, $30^{\circ}$ ). In the graphics, the working fluid, air, at $19{ }^{\circ} \mathrm{C}$ enters the channel from the right hand side and leaves the duct from the left hand side by sweeping the fins. In (a) showing the $0{ }^{\circ}$ facing position, along all the axes on the graph, it is seen that the velocity lines are irregular at both the entrance and exit of the fins. It can be said that among all velocity lines, only the velocity measured along $0.08 \mathrm{~m}$ increased at the exit zone but it decreased along all other lines. In (b) showing the $15^{\circ}$ facing position, it is seen that the velocity lines are stable along all axis lines, both at the entrance and at the exit. The value of velocity lines at the exit is slightly higher than that at the entrance. Finally, in (c) showing the $30^{\circ}$ facing position, it is seen that the value of the velocity lines at the exit is less than the value of the velocity lines at the entrance and there is an unstable velocity distribution.
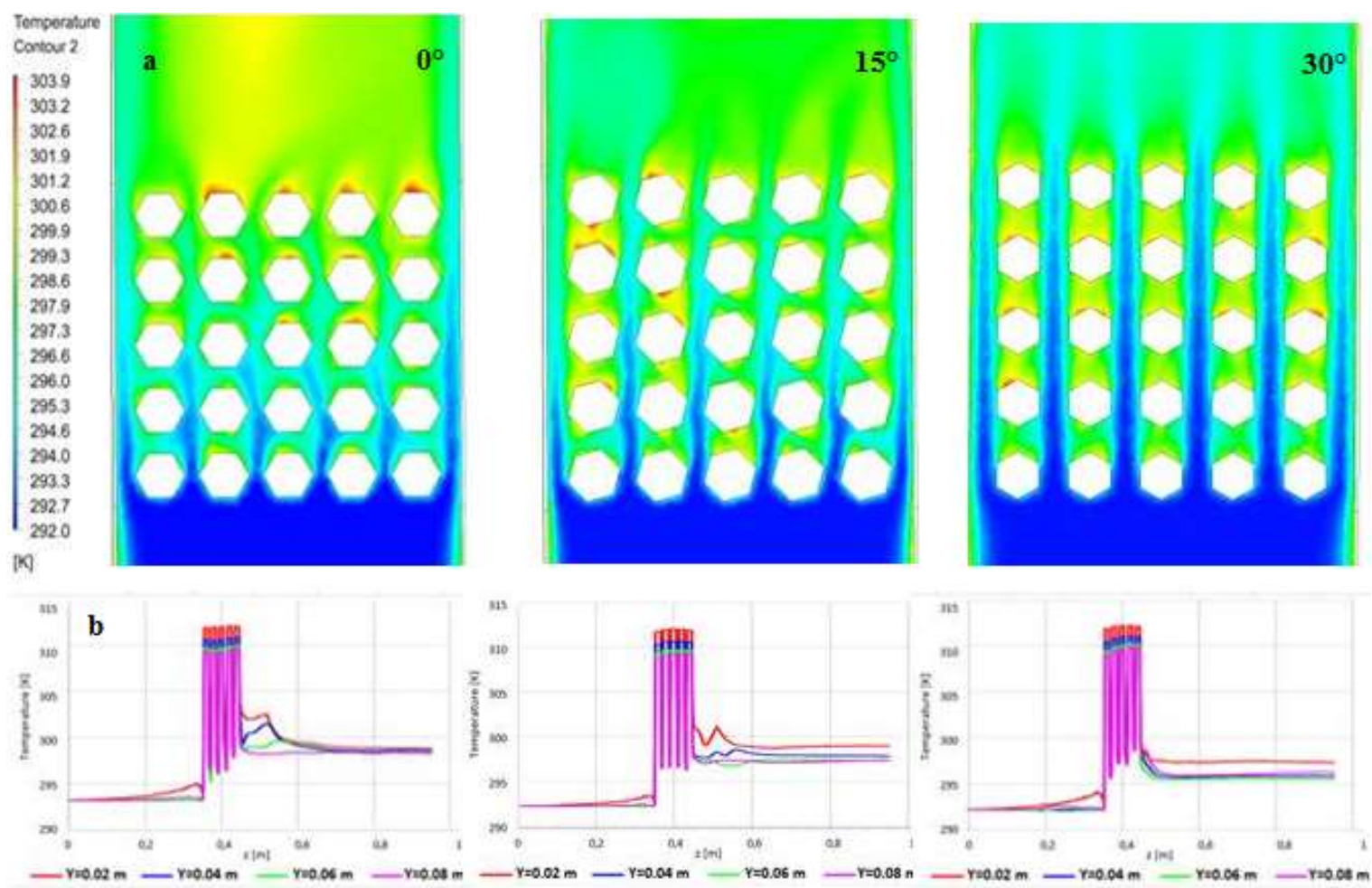

Figure 7. (a) Temperature distribution contours in the fin zone (b) Temperature values on different lines in the channel

Şekil 7. (a) Kanat bölgesindeki sıcaklık dağıllım konturları (b) Kanalda farklı hatlardaki sıcaklık değerleri 
Temperature distribution in the fin zone is shown in Figure 7 (a). It will be more useful to evaluate the distribution here in two sections: between the fins and beyond the fins. Temperature between the fins remain low until the $3 \mathrm{rd}$ row in the $0^{\circ}$ position, and in the 4th and 5th rows, temperature build-up is observed in the upper parts of the hexagonal fins. In this arrangement, it can be said that the temperature increases at the back of the fins and leave the zone. As for the $15^{\circ}$ arrangement, temperatures increase between the fins starting from the 1st row, and temperature build-up occurs in some of the fins in the 3rd, 4th and 5th rows. It was observed that the temperature of the working fluid, air, increased at the exit of the fin zone and thus left that section and that the temperature distribution was relatively homogeneous. In the $30^{\circ}$ facing arrangement, the temperature between the fins gradually increases from the 1 st row to the 5 th row, and that there is a temperature build-up at the back of the fins in the $3 \mathrm{rd}$ and 4 th rows. At the exit of the fin zone, the temperature is seen to have increased only in the alignments of the fins, and thus left the zone, while the other zones remain relatively cool.

Figure 7 (b) shows temperature distributions along different lines at the channel inlet, across the fins and at the channel outlet. The working fluid enters the duct from the right hand side at $19^{\circ} \mathrm{C}$, sweeps the fins and leaves the duct from the left hand side. When the temperature distributions across the hexagonal fins at $0^{\circ}$ and $30^{\circ}$ arrangements are examined; the temperature is seen as stable both at the channel entrance and at the exit, at all axes, except for a gradual increase in the temperature distribution on the fins for $0.08 \mathrm{~m}$ axis. Likewise, when the temperature distribution of the hexagonal fins with $15^{\circ}$ facing arrangement is examined; it is seen that velocity distributions are stable both at the channel entrance, across the fins and at the channel exit.

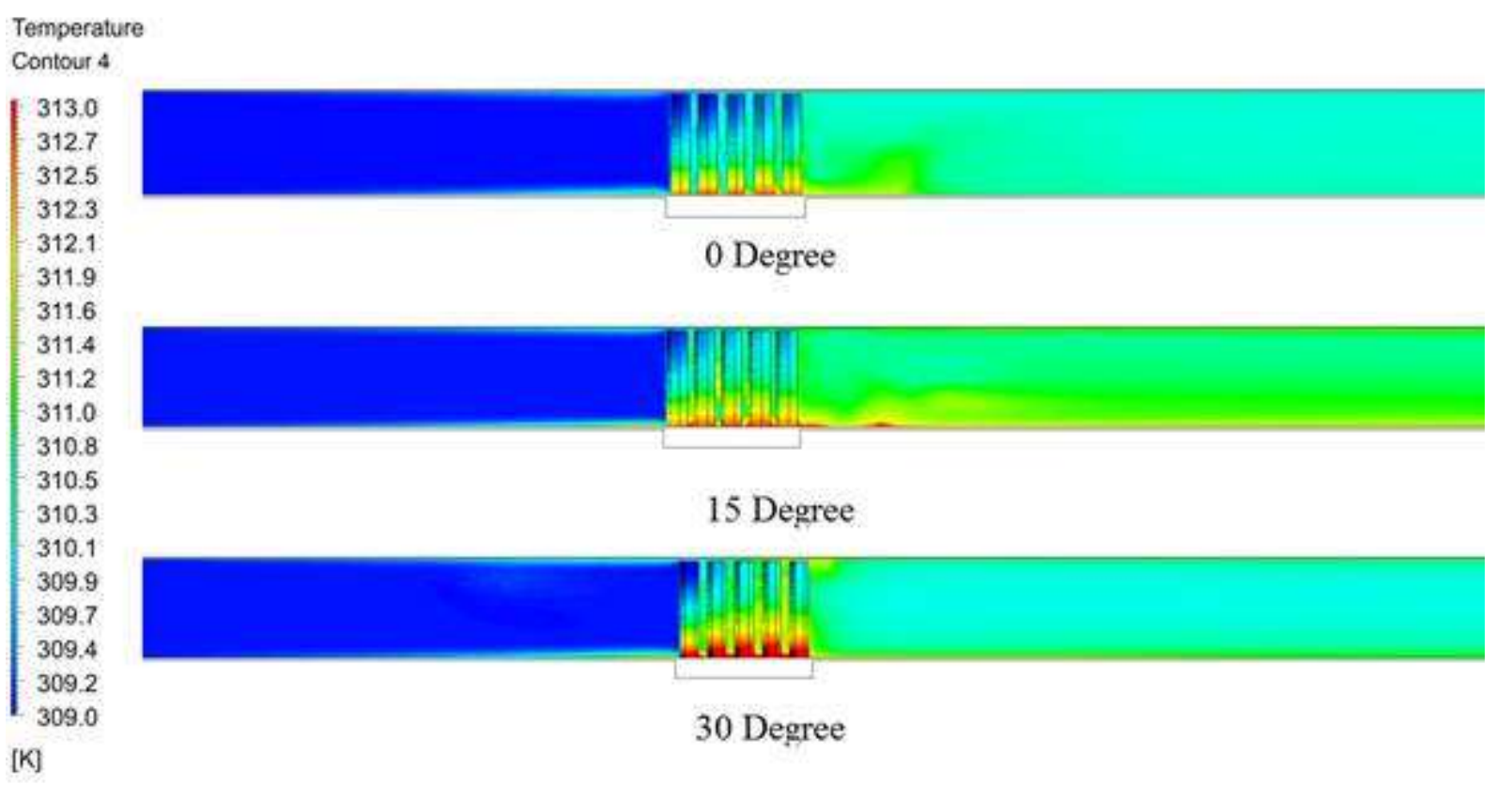

Figure 8. Temperature distribution inside the channel and across the fins

Şekil 8. Kanal içinde ve kanatçıklar boyunca sıcaklık dağılımı

Figure 8 shows the temperature distribution both inside the channel and across the fins. When examined; it is seen in the figure that the temperature distribution across the fins is best in the cases of $0^{\circ}$ and $15^{\circ}$ facing positions, while the temperatures of the fins are higher in the $30^{\circ}$ position, where there has not been enough heat dissipation. Considering the temperature distribution along the channel, it can be clearly said that the arrangement in the case of which air leaves the channel at the highest temperature and homogeneously is the $15^{\circ}$ one. In the cases of $0^{\circ}$ and $30^{\circ}$ facing positions, the working fluid, air, could not absorb enough heat through the fins and hence could not perform a good cooling.

\section{Conclusion \\ 4. Sonuçlar}

According to the results of the numerical analysis carried out on the same array of hexagonal fins having the same alignment but with different facing angles: 
- due to that there is more turbulence and vortices between the hexagonal fins placed at $15^{\circ}$ facing angle, the velocity profile is higher for the same heat transfer surface area, and therefore the pumping power could decrease further.

- when the heat distribution along the entire channel is examined; the temperatures were high through the end of the channel, which means that more heat was drawn when fins are positioned in at $15^{\circ}$.

- In the case of $0^{\circ}$ arrangement, temperature build-up was observed just at back end of the fins and the desired level of heat dissipation could not be achieved.

- For future studies, it is evaluated that performing experimental and numerical analyzes with fins rotated by $15^{\circ}$ on different fin arrays and geometries could yield better results in terms of heat transfer and pumping power.

The results of this study are in agreement with Soleymani et al (2020), and the design and direction of the fins causes turbulence at the outlet and improves the temperature distribution, hence the heat transfer.

\section{Author contribution \\ Yazar katkısı}

The author provided the literature review of the article, the preparation of the model, the numerical analysis and evaluation, the preparation of all figures and tables, the evaluation of the results and the preparation of the references.

\section{Declaration of ethical code}

Etik beyanı

The author of this article declares that the materials and methods used in this study do not require ethical committee approval and/or legal-specific permission.

\section{Conflicts of interest \\ Çıkar çatışması beyanı}

The author declares that there is no conflict of interest.

\section{References}

Kaynaklar

Acharya, S., Dutta, S., Myrum, T., \& Baker, R. (1993). Periodically developed flow and heat transfer in a ribbed duct. International Journal of Heat and
Mass Transfer, 36(8), 2069-2082. https://doi.org/10.1016/S0017-9310(05)80138-3

Adhikari, R., Wood, D., \& Pahlevani, M. (2020). Optimizing rectangular fins for natural convection cooling using cfd. Thermal Science and Engineering Progress, 17, 100484. https://doi.org/10.1016/j.tsep.2020.100484

Ahmadian-Elmi, M., Mashayekhi, A., Nourazar, S., \& Vafai, K. (2021). A comprehensive study on parametric optimization of the pin-fin heat sink to improve its thermal and hydraulic characteristics. International Journal of Heat and Mass Transfer, 180, 121797. https://doi.org/10.1016/j.ijheatmasstransfer.202 1.121797

Briggs, D., \& London, A. L. (1960). The heat transfer and flow friction characteristics of five offset rectangular and six plain triangular plate-fin heat transfer surfaces. Technical report no. 49. Stanford Univ., Calif.: https://www.osti.gov/biblio/4068664

Buyruk, E., \& Karabulut, K. (2017). Plakalı kanatçıklı isı değiştiricilerde kanat geometrisinin isı transferine olan etkisinin üç boyutlu sayısal olarak İncelenmesi. Dokuz Eylül Üniversitesi Mühendislik Fakültesi Fen ve Mühendislik Dergisi, 19(56), 346-363. https://doi.org/10.21605/cukurovaummfd.31005

Garg, V. K., \& Maji, P. (1988). Laminar flow and heat transfer in a periodically converging-diverging channel. International journal for numerical methods in fluids, 8(5), 579-597. https://doi.org/10.1002/fld.1650080506

Hung, S.C., Huang, S.C., \& Liu, Y.H. (2019). Effect of nonuniform pin size on heat transfer in a rotating rectangular channel with pin-fin arrays. Applied Thermal Engineering, 163, 114393. https://doi.org/10.1016/j.applthermaleng.2019.1 14393

Karabulut, K., Buyruk, E., Kılınç, F., \& Karabulut, Ö. O. (2013). Farklı geometrilerden oluşan kanatçıklı plakalı isı değiştiricileri için isı transferinin üç boyutlu sayısal olarak İncelenmesi, 11. Ulusal Tesisat Müh. Kongresi, $17-20$

Kays, W. M., \& London, A. L. (1954). Compact heat exchangers--a summary of basic heat transfer and flow friction design data. To 6, Technical report no. 23. Stanford Univ., Calif.: https://www.osti.gov/biblio/4380526

Kotcioglu, İ., \& Bolukbasi, A. (2003). Experimental investigation heat transfer in different wingletsurfaces in a vertical rectangular duct. Dokuz Eylul University, Faculty of Engineering, 
Journal of Science and Engineering, 5(2), 89102

Kotçioğlu, İ., Ayhan, T., Olgun, H., \& Ayhan, B. (1998). Heat transfer and flow structure in a rectangular channel with wing-type vortex generator. Turkish Journal of Engineering and Environmental Sciences, 22(3), 185-196

Lee, C., \& Abdel-Moneim, S. (2001). Computational analysis of heat transfer in turbulent flow past a horizontal surface with two-dimensional ribs. International Communications in Heat and Mass Transfer, 28(2), 161-170. https://doi.org/10.1016/S0735-1933(01)00223-8

Masao, F., Yu, S., \& Goro, Y. (1988). Heat transfer and pressure drop of perforated surface heat exchanger with passage enlargement and contraction. International Journal of Heat and Mass Transfer, 31(1), 135-142. https://doi.org/10.1016/0017-9310(88)90230-X

Maughan, J., \& Incropera, F. (1991). Use of vortex generators and ribs for heat transfer enhancement at the top surface of a uniformly heated horizontal channel with mixed convection flow. Journal of Heat Transfer - Transactions of The ASME, 113(2), 504-507. https://doi.org/10.1115/1.2910592

Mesler, R. (1993). Surface roughness and its effects on the heat transfer mechanism of spray cooling. Journal of Heat Transfer-Transactions of The ASME, 115(4), 1083-1083. https://doi.org/10.1115/1.2911248

Russell, A. M., \& Lee, K. L. (2005). Structure-property relations in nonferrous metals (Vol. 302): Wiley Online Library

Soleymani, Z., Rahimi, M., Gorzin, M., \& Pahamli, Y. (2020). Performance analysis of hotspot using geometrical and operational parameters of a microchannel pin-fin hybrid heat sink. International Journal of Heat and Mass Transfer, $\quad 159, \quad 120141$. https://doi.org/10.1016/j.ijheatmasstransfer.202 0.120141

Souza Mendes, P., \& Sparrow, E. (1984). Periodically converging-diverging tubes and their turbulent heat transfer, pressure drop, fluid flow, and enhancement characteristics. Journal Heat Trasnfer, 106(1), 55-63. https://doi.org/10.1115/1.3246659.

Sundén, B. (1999). Heat transfer and fluid flow in ribroughened rectangular ducts. In Heat transfer enhancement of heat exchangers (pp. 123-140): Springer

Tauscher, R., \& Mayinger, F. (1999). Heat transfer enhancement in a plate heat exchanger with ribroughened surfaces. In Heat transfer enhancement of heat exchangers (pp. 207-221): Springer

Wang, Y. Q., Dong, Q.W., Liu, M.S., \& Wang, D. (2009). Numerical study on plate-fin heat exchangers with plain fins and serrated fins at low reynolds number. Chemical Engineering \& Technology: Industrial Chemistry-Plant Equipment-Process Engineering-Biotechnology, 32(8), 1219-1226. https://doi.org/10.1002/ceat.200900079

Wen, J., Li, K., Zhang, X., Wang, C., Wang, S., \& Tu, J. (2018). Optimization investigation on configuration parameters of serrated fin in platefin heat exchanger based on fluid structure interaction analysis. International Journal of Heat and Mass Transfer, 119, 282-294. https://doi.org/10.1016/j.ijheatmasstransfer.201 7.11 .058

Wen, J., Yang, H., Tong, X., Li, K., Wang, S., \& Li, Y. (2016). Optimization investigation on configuration parameters of serrated fin in platefin heat exchanger using genetic algorithm. International Journal of Thermal Sciences, 101, 116-125.

https://doi.org/10.1016/j.ijthermalsci.2015.10.02 4 